Journal of Indonesian Physical Education and Sport

p-ISSN 2442-4900 | e-ISSN 2461-1271

Vol. 4, No.1, July 2018, p 100-117

\title{
THE EVALUATION OF TEACHER PROFESSIONAL EDUCATION PROGRAM BACHELOR OF EDUCATION IN THE FOREMOST, OUTER AND BEHIND PROGRAM THE EDUCATION OF PHYSICAL, HEALTH AND RECREATION IN STATE UNIVERSITY OF JAKARTA
}

\author{
Iwan Setiawan, \\ State University of Jakarta \\ Iwansport53@yahoo.coM
}

\begin{abstract}
This study aims to evaluate the Teacher Professional Education Program Bachelor of Education In The Foremost, Outer And Behind program in Jakarta State University. The research of Teacher Professional Education Program Bachelor of Education In The Foremost, Outer And Behind program evaluation used CIPP model of Daniel L. Suffebeam because this approach fits the research objectives describing the Teacher Professional Education Program Bachelor of Education In The Foremost, Outer And Behind program. The instruments used were the researcher himself, interview guidance, questionnaires, and documentation. Data analysis was done in accordance with Miles and Huberman namely; data reduction, data display, and conclusion. The results found were: 1) context aspect namely: that Teacher Professional Education Program Bachelor of Education In The Foremost, Outer And Behind program had agreed with the objectives, had a strong legal basis, and needs analysis namely to assist the acceleration of government programs for equitable education; 2) input aspects namely: program plan and facilities in the form of human resources such as lecturers, Teacher Professional Education Program participants, facilities and infrastructure, funding, partnership and management were available well according to the plan; 3) process aspects, namely the implementation of the activities, including: the implementation of the evaluation process, decision-making process, learning process, and graduation process had already run well; 4) product aspects namely Teacher Professional Education Program Bachelor Of Education In The Foremost, Outer And Behind Program of Education of Physical, Health and Recreation study program of Jakarta State University had been able to improve the quality and quantity of participants, including the number of graduates. Based on the results of this evaluation, it can be concluded that Teacher Professional Education Program Bachelor of Education In The Foremost, Outer And Behind program had been implemented as well as possible but it needed improvement of facilities and infrastructure, funds, and coordination between the ministry of research and technology of higher education and Teacher Training Institute of Jakarta State University.
\end{abstract}

Keywords: Program Evaluation, Teacher Professional Education Program Bachelor of Education In The Foremost, Outer And Behind, CIPP Model, and Education of Physical, Health and Recreation.

Teacher Professional Education Program Bachelor Of Education In The Foremost, Outer And Behind program is one of the government's programs to address education issues in the foremost, outermost and underdeveloped areas. Educational issues in the foremost, outermost and underdeveloped areas related to educators are; the lack of the number of teacher (shortage), unbalanced distribution, under qualification, low competencies, and educational qualification does not match the subject taught (mismatched). Other issues of the importance of the implementation of education in the foremost, outermost and underdeveloped areas are; relatively high drop out rates, low school enrollment rates, insufficient infrastructure, and infrastructure for easy access to education.

Based on the above problems, the government through the Ministry of Education and Culture created Going Together to Educate Indonesia Program. This program includes: (1) Bachelor Teaching in the foremost, outermost and underdeveloped Bachelor of Education In The Foremost, Outer And 
Behind Program, and (2) Teacher Professional Education Program Bachelor of Education In The Foremost, Outer And Behind program with three areas of achievement, namely (1) Bachelor Teaching in the foremost, outermost and underdeveloped areas related to the quality of teachers. (2) The problem of unequal amounts and distribustion of teachers (3) The Indonesian state is faced on the question of how to make Indonesian people into one nation. In the implementation of the program, not all higher education institutions can implement the activities of teacher education program (Teacher Professional Education Program) Bachelor of Education In The Foremost, Outer And Behind. Educational Institution of Education Personnel/ Education Institution of Educational Personnel (EIEP) that meets certain criteria or requirements, one of which is the readiness of facilities and infrastructure of the participants of the education of teacher profession stay or dormitory.

State University of Jakarta is one of the universities that has procurement program of qualified educational personnel, therefore State University of Jakarta hereby holds teacher profession education (Teacher Professional Education Program) Bachelor Of Education In The Foremost, Outer And Behind program which up to now has been running for 4 years. The fourth generation of Teacher Professional Education Program Bachelor of Education In The Foremost, Outer And Behind program year 2015/2016 was participated by participant candidates from 11 study programs and one of them was Education of Physical, Health and Recreation Program with 21 participants. Based on the monitoring of the Higher Education Team, the implementation issues of Teacher Professional Education Program-Bachelor of Education In The Foremost, Outer And Behind Program by Teacher Training Institute of Higher Education found, among others: (a) in academic implementation, the learning process in every faculty and nonacademic process in dormitory, the facilities and infrastructures were still minimum, (b) many schools of Field Experience Program placement locations had not known the existence of Teacher Professional Education Program Bachelor Of Education In The Foremost, Outer And Behind Program, it indicated lack of good coordination and socialization among the parties involved in the implementation of this program.

Based on the background of the problem and the focus of the research above, the researcher formulated the problem as follows; "Has the implementation of Teacher Professional Education Program Bachelor of Education In The Foremost, Outer And Behind Program on Education of Physical, Health and Recreation Study Program organized by educational institution of educational personnel (Teacher Training Institute) of Jakarta State University viewed from aspects of context, input, process and product been effective?".

Sukardi (2008: 1) states that evaluation is a process for the best decision-making based on the value or how well the program has been implemented. Djaali and Muljono (2008: 1) explain that evaluation is a systematic process to determine or to make decisions, to what extent the objectives of the program have been achieved.

Based on the experts' opinion above, it can be concluded that evaluation is an activity to collect information about the operation of how something works, which furthermore the information is used to determine the fixed alternative in making decision. Daniel L. Stufflebeam et. al (2004: 74) defines evaluation as the process of delineating, obtaining, and providing useful information for judging decision alternatives." This means that evaluation is the process of describing, obtaining, and presenting useful information to formulate an alternative decision.

Tangkudung (2012: 42) describes that program is a draft of the principles and the efforts to be implemented. Suharsimi Arikunto (2004: 3) said that the program has two meanings, namely the program in general and the program in particular. Program in general is plan or design of activities that are comprehensive, while the program in particular is the program directly related to the evaluation, which is a unit or unity of activities that is the implementation of a policy. While Sabari 
Musa (2005: 10) defines the evaluation of the program as an activity to obtain a picture of the state of an object done in planned, systematic with clear directions and objectives.

Daniel L. Stufflebeam (1984: 15) defines evaluation as the process of delineating, obtaining, and providing useful information to asses decision-making alternatives. The CIPP evaluation model proposed by Daniel Stufflebeam is a decision-oriented evaluation approach structured to provide assistance to administrators or decision-making leaders. CIPP is an abbreviation of the components of its evaluation namely contexts, input, process, and product. CIPP tries to describe the whole series of activities from the beginning of the activities until those activities control or achieve the targets set. Evaluation of CIPP model is embodied in figure. 1:

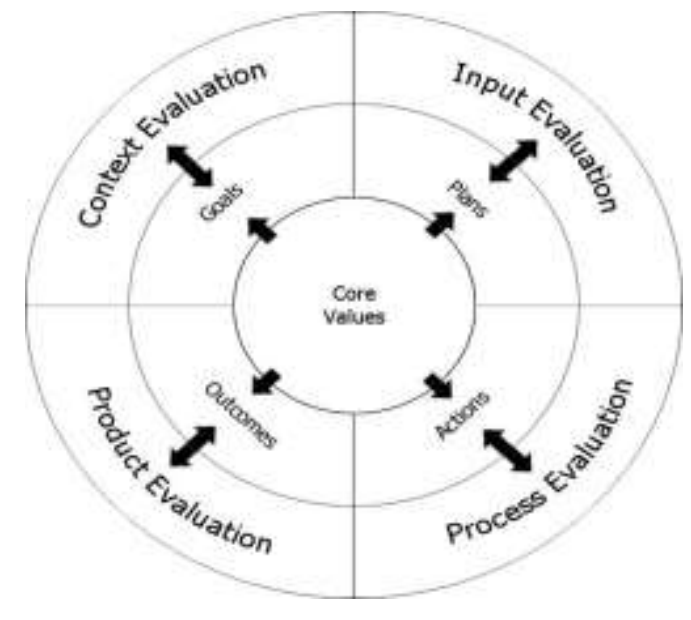

Figure 1. Key Components of CIPP Evaluation Model

Source: Daniel L. Stufflebeam and Anthony J. Shinkfield, Evaluation Theory, Models, \& AField experience programications, San Francisco: Jossey Bass, 2007.

The CIPP model consists of four types of evaluation, namely: context evaluation, input evaluation, process evaluation, and product evaluation. The explanation is as follows: context evaluation is the basis of the evaluation that aims to provide reasons (rationale) in the determination of a goal. Context evaluation includes analysis of problems related to the program environment or objective conditions to be implemented. Context evaluation includes: objectives, legal basis and needs analysis. The second stage of the CIPP model is input evaluation. Deniz Eseryel (2001, 1-9) states that input evaluation is conducted to get the answers to the question: what should be done? The stage of input evaluation is conducted by identifying the most likely strategy to achieve the desired result. Input evaluation includes: (1) Human resources, (2) Supporting facilities and equipment, (3) Funds or budgets, and (4) Partnerships.

According to Mohammad Abdul Wahid Usmani (2012, 230-252), process evaluation seeks to answer the question: How is the program implemented? Process evaluation is conducted by looking at the implementation, strategy, and seeing the implementation of the activities, including the collection of assessment data that has been determined and Field experience programs in the implementation practice of the program. Process evaluation is conducted by looking at the implementation, strategy, and viewing the implementation of the activity including: (1) evaluation process, (2) decision making process, (3) learning process and (4) determining the graduation. Product evaluation is directed to find the answers of question, did it Succeed? Assessment done was to see the achievement / success of a program in achieving predetermined goals. Product evaluation is an assessment conducted to see: (1) quality and (2) graduates achievement of a program in achieving predetermined objectives. 
Teacher Professional Education Program Bachelor of Education In The Foremost, Outer And Behind program is teacher profession education program for education undergraduates who have performed duties in foremost, outermost and underdeveloped areas for one year. The ministry of research and technology (2012): teacher education program (Teacher Professional Education Program Bachelor of Education In The Foremost, Outer And Behind) of physical education is profession education program to establish the professional competence of physical education teachers who teach in accordance with their competence or field of study. To measure the achievement of Teacher Professional Education Program Bachelor of Education In The Foremost, Outer And Behind program, it is necessary to conduct evaluation. The appropriate evaluation model for evaluating Teacher Professional Education Program Bachelor of Education In The Foremost, Outer And Behind program is CIPP model proposed by Stufflebeam and Shinkfield (1984: 151) viewed from: Context, Input, Process and Product. Each of them is described as follows:

Table. 1. Evaluation criteria of Teacher Professional Education Program Bachelor Of Education In The Foremost, Outer And Behind program of Education of Physical, Health and Recreation.

\begin{tabular}{|c|c|c|}
\hline Component & Evaluated aspect & Criteria \\
\hline Context & $\begin{array}{l}\text { 1. Objectives } \\
\text { 2. Legal basis } \\
\text { 3. Needs analysis }\end{array}$ & $\begin{array}{l}\text { a. The compatibility between objectives as well as relevance } \\
\text { and people's need. } \\
\text { b. Legal basis, following up the objectives of Teacher } \\
\text { Professional Education Program Bachelor of Education In } \\
\text { the Foremost, Outer And Behind achievement in line with } \\
\text { vision/ mission through government and Program } \\
\text { Supervisory Board action plan so it has strong legal force. } \\
\text { c. Needs analysis is Teacher Professional Education } \\
\text { Program Bachelor Of Education In The Foremost, Outer } \\
\text { And Behind program in teacher's quality according to } \\
\text { interest holder and education expert }\end{array}$ \\
\hline Input & $\begin{array}{l}\text { 1. Facilities and } \\
\text { infrastructure } \\
\text { 2. Human } \\
\text { Resources } \\
\text { 3. Fund support } \\
\text { 4. Partnership }\end{array}$ & $\begin{array}{l}\text { a. Facilities and infrastructure, is standard facilities and } \\
\text { infrastructure that support the program implementation } \\
\text { process are fulfilled. } \\
\text { b. Human Resource, is Program Supervisory Board } \\
\text { chairman gives socialization to Human Resource of } \\
\text { program executors (profession chairman, dormitory } \\
\text { manager, lecturer, teacher, tutor, participant) } \\
\text { c. The availability of fund source } \\
\text { d. The availability of partnership with other party in the } \\
\text { implementation }\end{array}$ \\
\hline Process & $\begin{array}{l}\text { The implementation } \\
\text { of Teacher } \\
\text { Professional } \\
\text { Education Program } \\
\text { activities include: } \\
\text { 1. Evaluation } \\
\text { process } \\
\text { 2. Decision making } \\
\text { process }\end{array}$ & $\begin{array}{l}\text { a. Teacher Professional Education Program evaluation } \\
\text { process, the availability of monitoring team in Teacher } \\
\text { Professional Education Program implementation } \\
\text { regularly. } \\
\text { b. Decision making process, the availability of coordination } \\
\text { between the leader and subordinate of program executor. } \\
\text { c. The management of Field Experience Program learning } \\
\text { process, the availability of socialization with partnership } \\
\text { school party. }\end{array}$ \\
\hline
\end{tabular}




\begin{tabular}{|l|l|l|l|}
\hline & $\begin{array}{l}\text { 3. Learning process } \\
\text { and } \\
\text { 4. Graduation } \\
\text { determining } \\
\text { process }\end{array}$ & $\begin{array}{l}\text { d. Graduation determination, participant graduation } \\
\text { includes workshop, Field Experience Program } \\
\text { implementation and written test. }\end{array}$ \\
\hline Product & $\begin{array}{l}\text { 1. The quality of } \\
\text { Teacher } \\
\text { Professional } \\
\text { Education } \\
\text { Program } \\
\text { participants }\end{array}$ & $\begin{array}{l}\text { a. The achievement of quality and quantity of participants } \\
\text { after attending Teacher Professional Education Program } \\
\text { Bachelor Of Education In The Foremost, Outer And } \\
\text { Behind program. } \\
\text { b. The achievement of participants graduation level after } \\
\text { attending the program }\end{array}$ \\
\hline
\end{tabular}

Source: Supriadi Rustad et. al., Guidance of Preposition Teacher Profession Education Program PostProgram Bachelor Of Education In The Foremost, Outer And Behind. Jakarta: Ministry of Research and Technology, 2015.

\section{METHOD}

This research aims to evaluate the implementation of Teacher Professional Education Program Bachelor Of Education In The Foremost, Outer And Behind program, education of physical, health and recreation in Jakarta State University. The evaluation of Teacher Professional Education Program Bachelor Of Education In The Foremost, Outer And Behind program was conducted with CIPP model of Stuffebeam (Context, Input, Process, and Product). The subject of this research were the stakeholder of Teacher Professional Education Program Bachelor Of Education In The Foremost, Outer And Behind program executor namely Teacher Professional Education Program participant, profession chairman, head of dormitory, head of study program and lecturer. In addition to the informants of stakeholder, the subjects of this research were documents related to Teacher Professional Education Program Bachelor Of Education In The Foremost, Outer And Behind Program.

Instruments used in this study were questionnaires, interview guidance, and documentation. Data were collected by giving questionnaires, conducting interviews, and observing the research object. More data collection is displayed in the following table:

Table. 2. Data Collection

\begin{tabular}{|c|c|c|}
\hline Research Object & Data Source & $\begin{array}{l}\text { Technique of } \\
\text { Collecting Data }\end{array}$ \\
\hline $\begin{array}{l}\text { a. Context components: } \\
\text { a. Objectives } \\
\text { b. Legal basis } \\
\text { c. Needs analysis }\end{array}$ & $\begin{array}{l}\text { Profession chairman, head of } \\
\text { dormitory, head of study program, } \\
\text { lecturer and Teacher Professional } \\
\text { Education Program participants }\end{array}$ & $\begin{array}{l}\text { Questionnaires, } \\
\text { interview, document } \\
\text { study }\end{array}$ \\
\hline $\begin{array}{l}\text { b. Input components: } \\
\text { a. The readiness of human resources } \\
\text { b. The availability of facilities and } \\
\text { infrastructure } \\
\text { c. The availability of fund } \\
\text { d. Partnership }\end{array}$ & $\begin{array}{l}\text { Profession chairman, head of } \\
\text { dormitory, head of study program, } \\
\text { lecturer and Teacher Professional } \\
\text { Education Program participants }\end{array}$ & $\begin{array}{l}\text { Questionnaires, } \\
\text { interview, document } \\
\text { study }\end{array}$ \\
\hline $\begin{array}{l}\text { c. Process components: } \\
\text { a. Evaluation process }\end{array}$ & $\begin{array}{l}\text { Profession chairman, head of } \\
\text { dormitory, head of study program, }\end{array}$ & $\begin{array}{l}\text { Questionnaires, } \\
\text { interview, document }\end{array}$ \\
\hline
\end{tabular}




\begin{tabular}{|l|l|l|}
\hline $\begin{array}{l}\text { b. Decision making process } \\
\text { c. Learning process } \\
\text { d. Graduation determining process }\end{array}$ & $\begin{array}{l}\text { lecturer and Teacher Professional } \\
\text { Education Program participants }\end{array}$ & study \\
\hline $\begin{array}{l}\text { d. Product components: } \\
\text { a. The achievement of participants' } \\
\text { graduation. }\end{array}$ & $\begin{array}{l}\text { Profession chairman, head of } \\
\text { dormitory, head of study program, } \\
\text { lecturer and Teacher Professional } \\
\text { b. The quality of participants }\end{array}$ & $\begin{array}{l}\text { Questionnaires, } \\
\text { interview, document } \\
\text { study }\end{array}$ \\
\hline
\end{tabular}

The table above is the researcher's guidance for collecting data and reducing data. Questionnaires data were collected and processed with the help of SPSS version 22 program. Data were analyzed by descriptive approach with the following steps: 1) data collection is in accordance with the evaluation components, 2) making data display and analyzing data by comparing the data obtained with predetermined criteria, 3) assessing and 4) making decision and making recommendation. To deepen the data on each components, the researcher conducted Hubermen analysis model. The Hubermen analysis is performed as shown below:

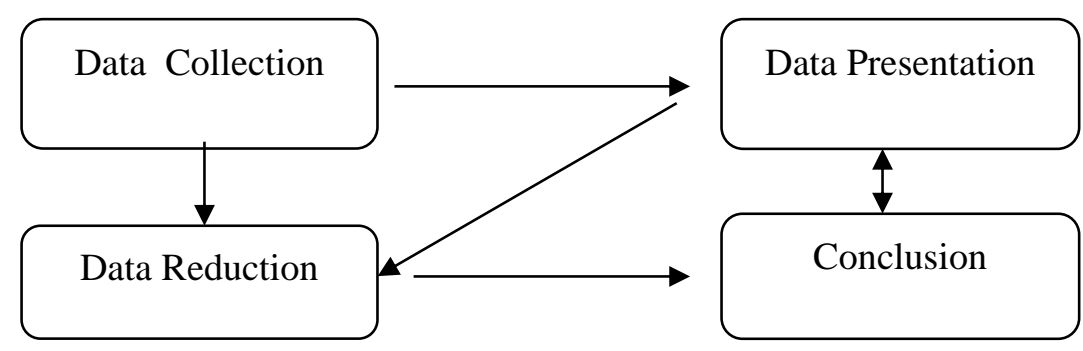

Picture. 2. Huberman's analysis (Emzir, 2010: 20).

To obtain accurate qualitative analysis result, the researcher checks the validity of the data criteria as follows: (1) credibility, to obtain reliable data, (2) conducting triangulation, by checking data to some informants, (3) dependability to confirm anything related to the neutrality and consistency of the data obtained, and (4) confirmability is done to obtain certainty of the data accuracy and the conclusion of the researcher.

\section{RESULTS}

Teacher Professional Education Program evaluation research was conducted with CIPP model. Evaluation was conducted on aspects of context, input, process, and product. The evaluation results of each components are as follows:

Table. 3. Summary Matrix of Teacher Professional Education Program Results and Assessment Indicators

\begin{tabular}{|c|c|c|c|c|c|c|}
\hline \multirow{2}{*}{\multicolumn{2}{|c|}{ INDICATC }} & \multicolumn{5}{|c|}{ INFORMANT } \\
\hline & & \multirow{2}{*}{$\begin{array}{l}\text { Profession } \\
\text { chairman }\end{array}$} & \multirow{2}{*}{$\begin{array}{l}\text { Head of } \\
\text { dormitory }\end{array}$} & \multirow{2}{*}{$\begin{array}{l}\text { Head of } \\
\text { tudy } \\
\text { rogram } \\
\text { Achieved }\end{array}$} & \multirow{2}{*}{$\begin{array}{l}\text { Lecturer } \\
\\
\text { Achieved }\end{array}$} & \multirow{2}{*}{$\begin{array}{l}\text { Teacher } \\
\text { Profession } \\
\text { al } \\
\text { Education } \\
\text { Program } \\
\text { participant } \\
\text { Match }\end{array}$} \\
\hline \multirow[t]{2}{*}{ Context } & Objectives & & & & & \\
\hline & Legal basis & Match & Match & Match & Match & Yes \\
\hline
\end{tabular}




\begin{tabular}{|l|l|l|l|l|l|l|}
\hline & Needs analysis & Available & Available & Available & Yes & Yes \\
\hline Input & Human Resource & Match & Enough & Adequate & S2/ S3 & S1 \\
\cline { 2 - 6 } & $\begin{array}{l}\text { The availability } \\
\text { of facilities/ } \\
\text { infrastructure }\end{array}$ & Adequate & Adequate & Adequate & $\begin{array}{l}\text { Not yet } \\
\text { satisfying }\end{array}$ & $\begin{array}{l}\text { Not yet } \\
\text { satisfying }\end{array}$ \\
\cline { 2 - 7 } & $\begin{array}{l}\text { The availability } \\
\text { of fund }\end{array}$ & $\begin{array}{l}\text { Fund source } \\
\text { from higher } \\
\text { education }\end{array}$ & Adequate & Adequate & Adequate & Good \\
\cline { 2 - 7 } & Partnership & Available & Available & Available & Available & Available \\
\hline Process & Evaluation & Smooth & Smooth & Smooth & Done & Available \\
\cline { 2 - 7 } & Decision making & Smooth & Smooth & Smooth & Smooth & Available \\
\cline { 2 - 7 } & Learning process & Smooth & Smooth & Smooth & Smooth & Smooth \\
\cline { 2 - 7 } & $\begin{array}{l}\text { Determining } \\
\text { graduation }\end{array}$ & Match & Match & Match & Match & Match \\
\hline Product & Quality & Good & Good & Good & Increasing & Increasing \\
\cline { 2 - 7 } & Graduation & Achieved & Achieved & Achieved & Achieved & Achieved \\
\hline
\end{tabular}

Based on the matrix above the implementation of Teacher Professional Education Program Bachelor Of Education In The Foremost, Outer And Behind that has been implemented so far is running well. However, the availability of supporting facilities and infrastructures has not been sufficient. Furthermore, the results of questionnaires distribution to the participants obtained the results that it was very helpful to improve the quality of education, especially in the remote areas. This is shown from the results of processed questionnaire data as follows:

Table. 4. The Results of Questionnaires from Participants

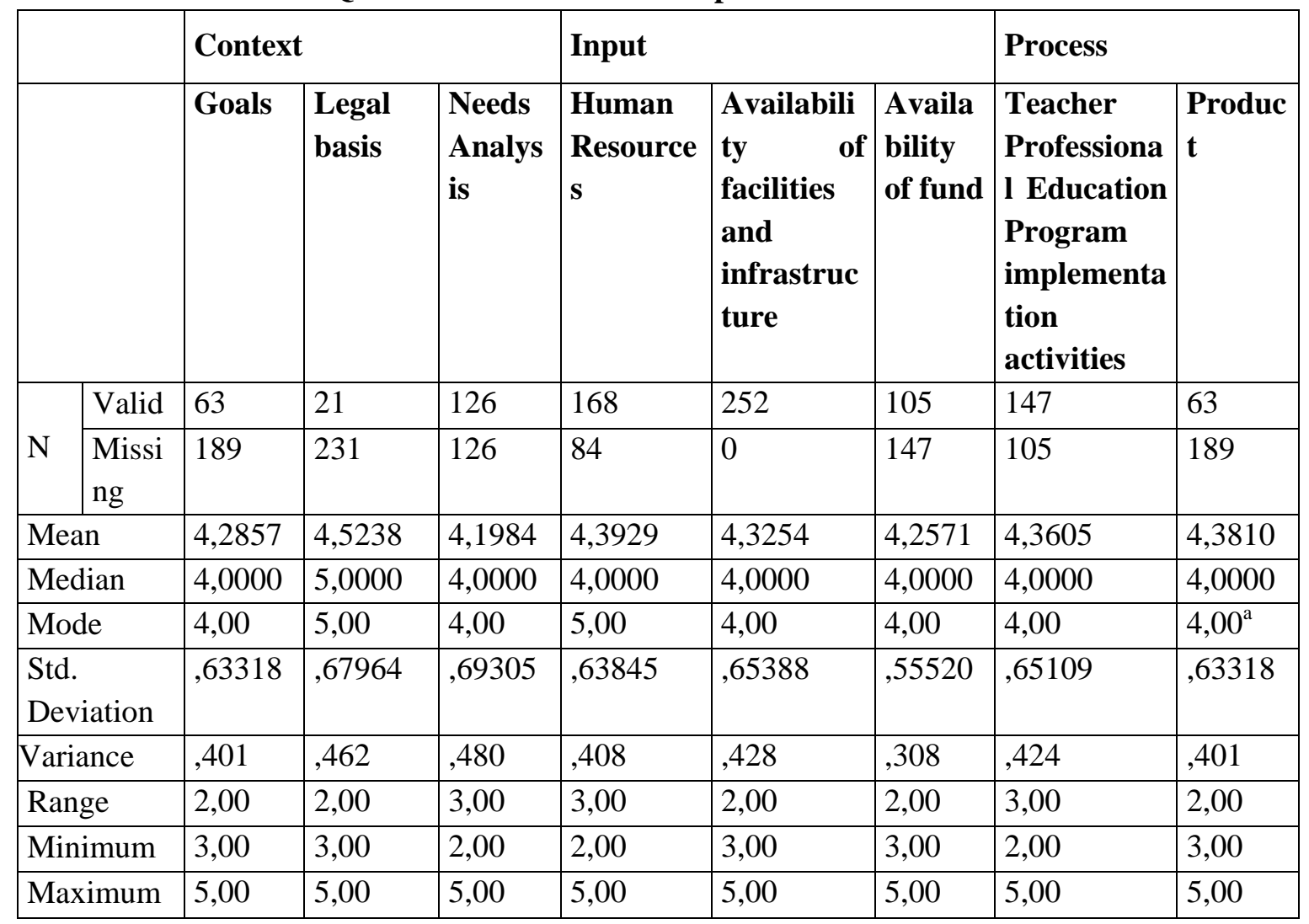




\begin{tabular}{|l|l|l|l|l|l|l|l|l|}
\hline Sum & 270,00 & 95,00 & 529,00 & 738,00 & 1090,00 & 447,00 & 641,00 & 276,00 \\
\hline
\end{tabular}
Multiple modes exist. The smallest value is shown

Based on the results of questionnaires from participant students of Teacher Professional Education Program Bachelor Of Education In The Foremost, Outer And Behind implementers, the average score of questionnaires was 4.2 - 4.5. The results of the assessment on the objectives were 270, legal basis were 95, and needs analysis were 529. For human resources input were 738, facilities and infrastructure were 1090, and availability of fund were 447. As for the process; implementation activities were 641 , and product were 276 . The results of interviews, questionnaires about this will be described more clearly as follows:

\section{Context Evaluation}

Context evaluation includes issues related to the program environment that have been implemented. The evaluation of the context component includes: (a) the objectives (b) the legal basis, and (c) needs analysis. Indicators of objectives, legal basis, and needs analysis show good results. This can be seen from the questionnaire results of Teacher Professional Education Program Bachelor Of Education In The Foremost, Outer And Behind program participants in the graph below:

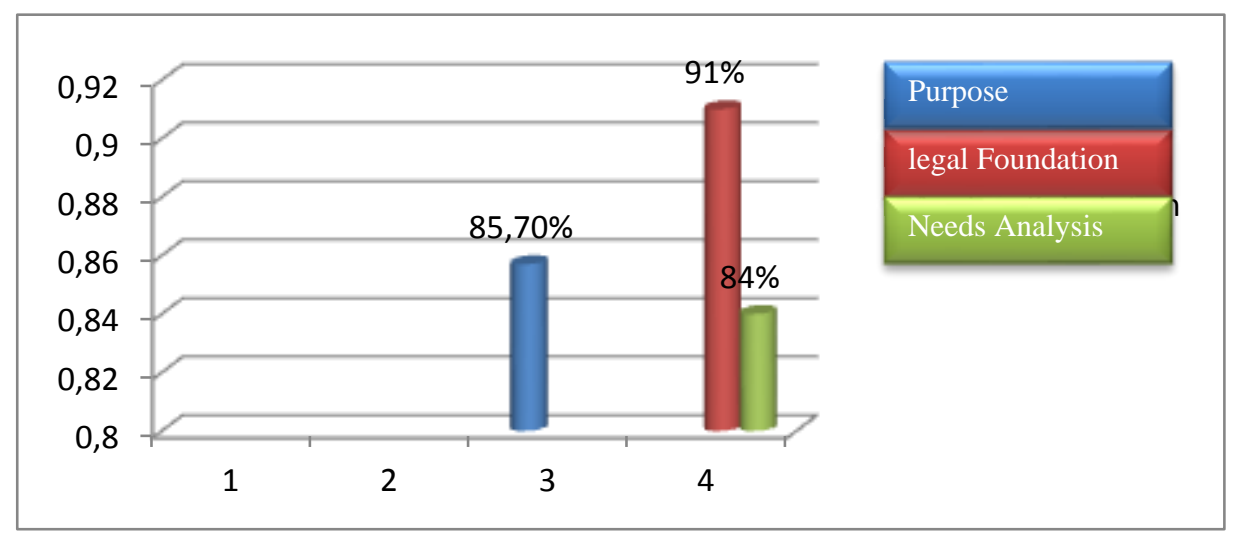

\section{Picture. 3. The Results of Context Questionnaire from Teacher Professional Education Program Bachelor Of Education In The Foremost, Outer And Behind Participants.}

The results of the context questionnaire above show excellent results. The result for Teacher Professional Education Program objectives was $85.70 \%$, legal basis $91 \%$, and needs analysis $84 \%$ of Teacher Professional Education Program Bachelor of Education In The Foremost, Outer And Behind participants. as a whole shows that the context of Teacher Professional Education Program Bachelor of Education In The Foremost, Outer And Behind starting from the objectives, preparation and legal basis that have been made by Jakarta State University was in accordance with the vision and mission that exist in Teacher Professional Education Program Bachelor of Education In The Foremost, Outer And Behind objectives.

\section{Input Evaluation}

Input Evaluation in Teacher Professional Education Program Bachelor Of Education In The Foremost, Outer And Behind program is seen from Human Resources, Availability of Facilities and Infrastructure, and Availability of Fund. The results of questionnaires related to input viewed from the three aspects are as follows: 


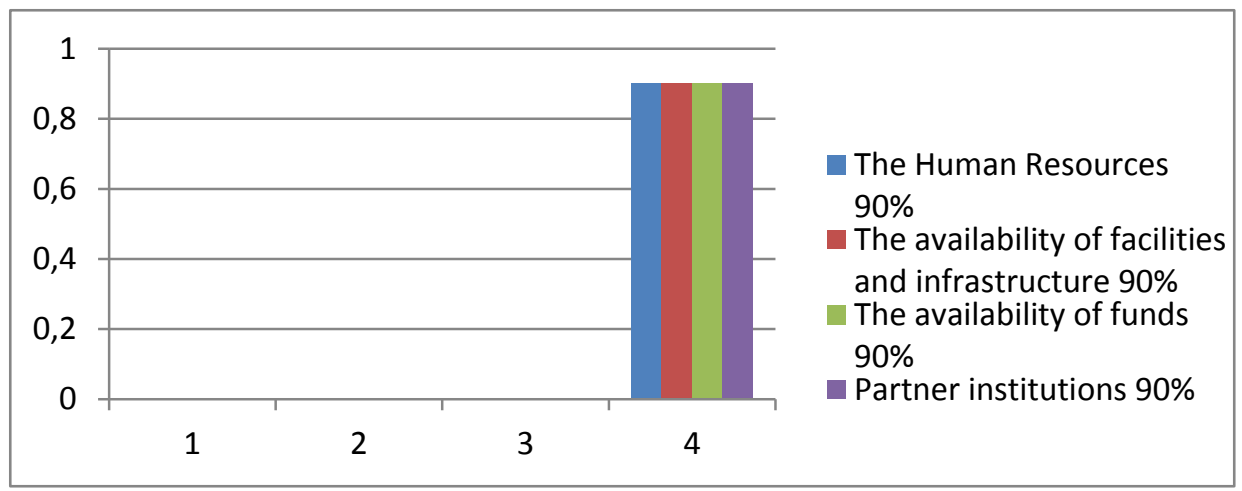

Picture. 4. Input Evaluation of Teacher Professional Education Program Bachelor Of Education In The Foremost, Outer And Behind Program

The human resources in Teacher Professional Education Program Bachelor Of Education In The Foremost, Outer And Behind program 90\% were in very good category. The availability of facilities and infrastructure $90 \%$ were in very good category. Finally the availability of funds $90 \%$ were also in very good category. Each of them is described as follows:

The human resources in Teacher Professional Education Program Bachelor Of Education In The Foremost, Outer And Behind program were Profession Chairman, Head of Dormitory, Head of Study Program, Teacher Professional Education Program Lecturer, And Teacher Professional Education Program Participant. Profession chairman is the duty doer of the chairman of the central of profession education and teachers certification as well as lecturers of educational development institution of State University of Jakarta. The head of the dormitory is the manager coordinator of Simple Rental Flats Rent 1 of State University of Jakarta. The head of study program of Education of Physical, Health and Recreation. For lecturers who deliver the material of Teacher Professional Education Program Bachelor Of Education In The Foremost, Outer And Behind program, the average of lecturers qualification who provide materials of Teacher Professional Education Program Bachelor Of Education In The Foremost, Outer And Behind have education qualification of master program (S2) or Doctoral (S3) and have educational background in accordance with the ones taught, and have expertise certificate that match the field being taught.

Next, Teacher Professional Education Program Bachelor Of Education In The Foremost, Outer And Behind participants were students who had completed Strata I or Bachelor of Education with the background of Bachelor of Sport Education or Bachelor of Sport, Health and Recreation Education. Teacher Professional Education Program Bachelor Of Education In The Foremost, Outer And Behind participants had met the requirements standards such as: tough, resilience, and healthy physical condition. Participant students of Teacher Professional Education Program Bachelor Of Education In The Foremost, Outer And Behind lived in dormitory, and have followed all programmed and conditioned activities.

Facilities and infrastructure provided by Jakarta State University were adequate. On average, ninety percent of Teacher Professional Education Program Bachelor of Education In The Foremost, Outer And Behind program participants strongly agree and agree that the supporting facilities and infrastructure of Teacher Professional Education Program Bachelor of Education In The Foremost, Outer And Behind program activities could help the implementation of the program. The availability 
of funds for the provision of Teacher Professional Education Program Bachelor of Education In The Foremost, Outer And Behind program was very adequate. Funds come from the Directorate General of Learning and Student Affairs of the Ministry of Research, Technology and Higher Education. The biggest obstacle of the availability of funds was the late of the funds shipment from the Directorate General of Learning and Student Affairs of the Ministry of Research, Technology and Higher Education to State University of Jakarta. This causes some activities should be delayed such as late payment of instructors' fee.

The results of questionnaires from the participants related to input evaluation viewed from human resources, availability of facilities and infrastructure, and availability of funds can be seen from the results of data processing as follows:

\section{Process Evaluation}

The results of process evaluation of Teacher Professional Education Program Bachelor Of Education In The Foremost, Outer And Behind program was the General Monitoring and Evaluation conducted during State University of Jakarta leadership meeting attended by Program Supervisory Board Chairman and his staff as Teacher Professional Education Program Bachelor of Education In The Foremost, Outer And Behind State University of Jakarta manager. In the meeting, the head of the university could perform direct evaluation to Teacher Professional Education Program Bachelor Of Education In The Foremost, Outer And Behind program implementers. The results of the questionnaires on the process of Teacher Professional Education Program Bachelor of Education In The Foremost, Outer And Behind program are as follows;

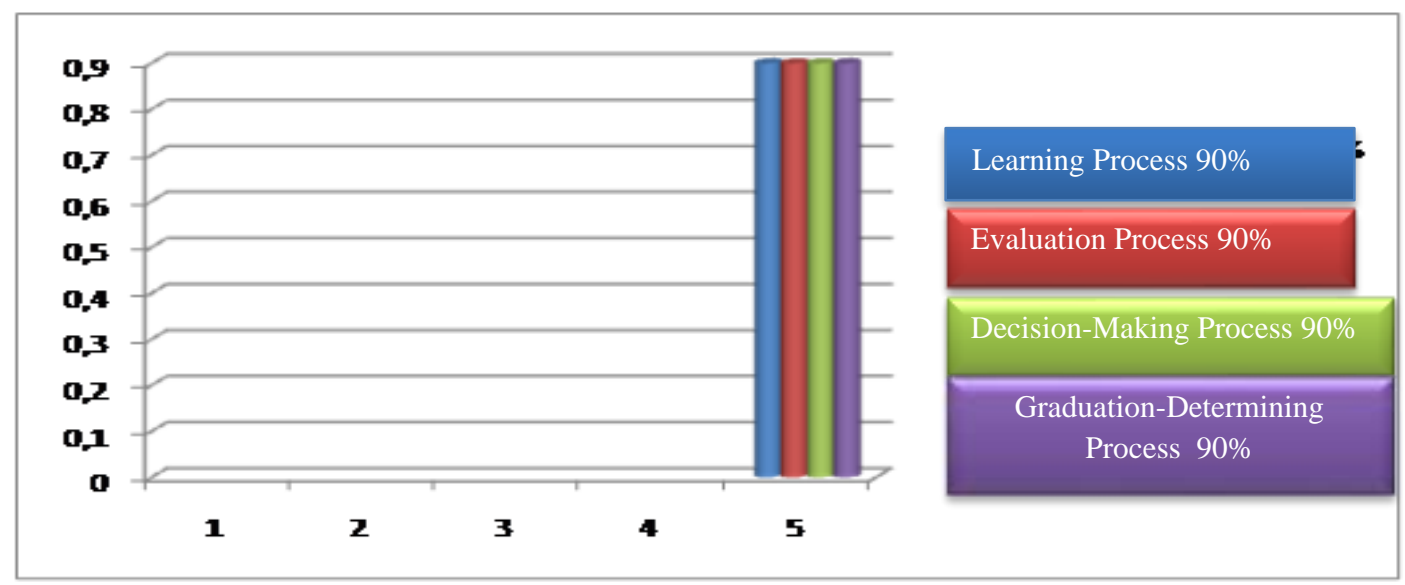

\section{Picture. 4. Process Evaluation of Teacher Professional Education Program Bachelor Of Education In The Foremost, Outer And Behind}

The implementation of Teacher Professional Education Program Bachelor of Education In The Foremost, Outer And Behind program had $90 \%$ been well implemented. Implementation carried out with stakeholder coordination could take place during the initial orientation of TEACHER Professional Education Program, followed by school and teacher inclusion either during peer teaching or Field Experience Program and Classroom Action Research. The problem found was the lack of discipline of some participants who did not comply the provisions when asking permission to leave the dormitory. Other problem was in the workshop, although the classroom had been prepared in the building of Study Center and Teacher Certification on 6th floor, sometimes the participants had to move to faculty of Sport Science building in campus B closer to the dormitory. Evaluation to the product of Teacher Professional Education Program Bachelor Of Education In The Foremost, Outer And Behind program implemented by Jakarta State University from regeneration in the sense of 
increasing the number of participants did not exist, considering the participants' quota of each Teacher Training Institute was the authority of the ministry.

\section{Product Evaluation}

The products or results that can be seen from Teacher Professional Education Program Bachelor Of Education In The Foremost, Outer And Behind program are: output, covering outcomes achieved by Teacher Professional Education Program Bachelor of Education In the Foremost, Outer And Behind program managers such as $80 \%$ graduates, and outcomes, including long-term impact on professionalism development of a prospective teacher and the improvement of education quality. The results of questionnaires on the product of Teacher Professional Education Program Bachelor of Education In The Foremost, Outer and Behind program are as follows;

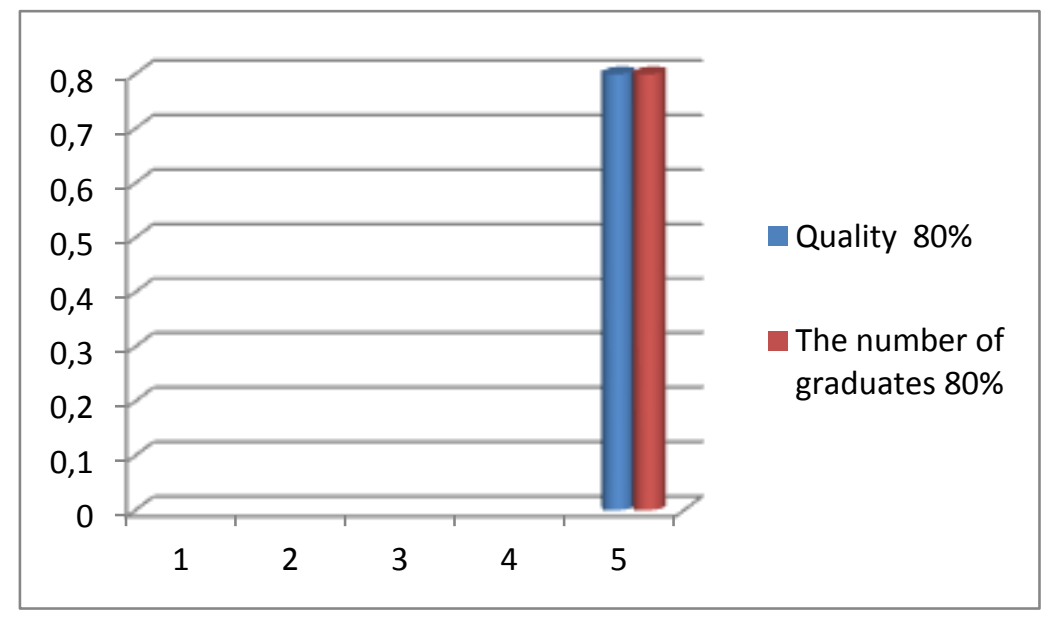

Picture 6. Product Result

The activities of Teacher Professional Education Program Bachelor of Education In the Foremost, Outer And Behind program implementation highly approved by the participants can improve the quality of education as well as the product of Teacher Professional Education Program Bachelor of Education In The Foremost, Outer And Behind program can improve the quality and professionalism of teachers as much as $80 \%$. In general, the graduation of Teacher Professional Education Program Bachelor of Education In The Foremost, Outer and Behind participants of Physical, Health, and Recreation Education was very satisfactory, all participants achieved 95\% graduation rate on the main National Writing Exam. This indicates that they were qualified as professional teachers.

\section{Context Evaluation}

\section{DISCUSSION}

Findings on context evaluation was focused on three aspects of evaluation: (1) objectives, (2) legal basis, and (3) needs analysis. Objectives are often expressed as targets and aspirations. Salis (2012: 219) explains the goal should be expressed in a measured method so that the end result can be evaluated by using that method. Judging from the results of $100 \%$ participant's graduation had been achieved, Teacher Professional Education Program Bachelor of Education In The Foremost, Outer And Behind program for the foremost, outermost and underdeveloped areas can help solve teacher problems, lack of number of teachers, unbalanced distribution, inadequate competence, and 
inconsistencies between the areas under study. Other problems include low drop-out rates, inadequate facilities and infrastructure, and infrastructure for easy access to education. The results of the questionnaire on the context of Teacher Professional Education Program Bachelor Of Education In The Foremost, Outer And Behind related to the objectives, legal basis and needs analysis show that Teacher Professional Education Program participants' understanding of the goals, legal basis, and needs analysis of Teacher Professional Education Program Bachelor Of Education In The Foremost, Outer And Behind program were excellent.

\section{Input Evaluation}

The input evaluation includes; human resources, the availability of facilities and infrastructure, and the availability of fund. Human resources both from participants and lecturers had met the criteria in accordance with standards that had been determined by ministry of research and technology. Qualified human resources is one of the keys to success. Based on the observations related to human resources can be seen from figure 7 below:

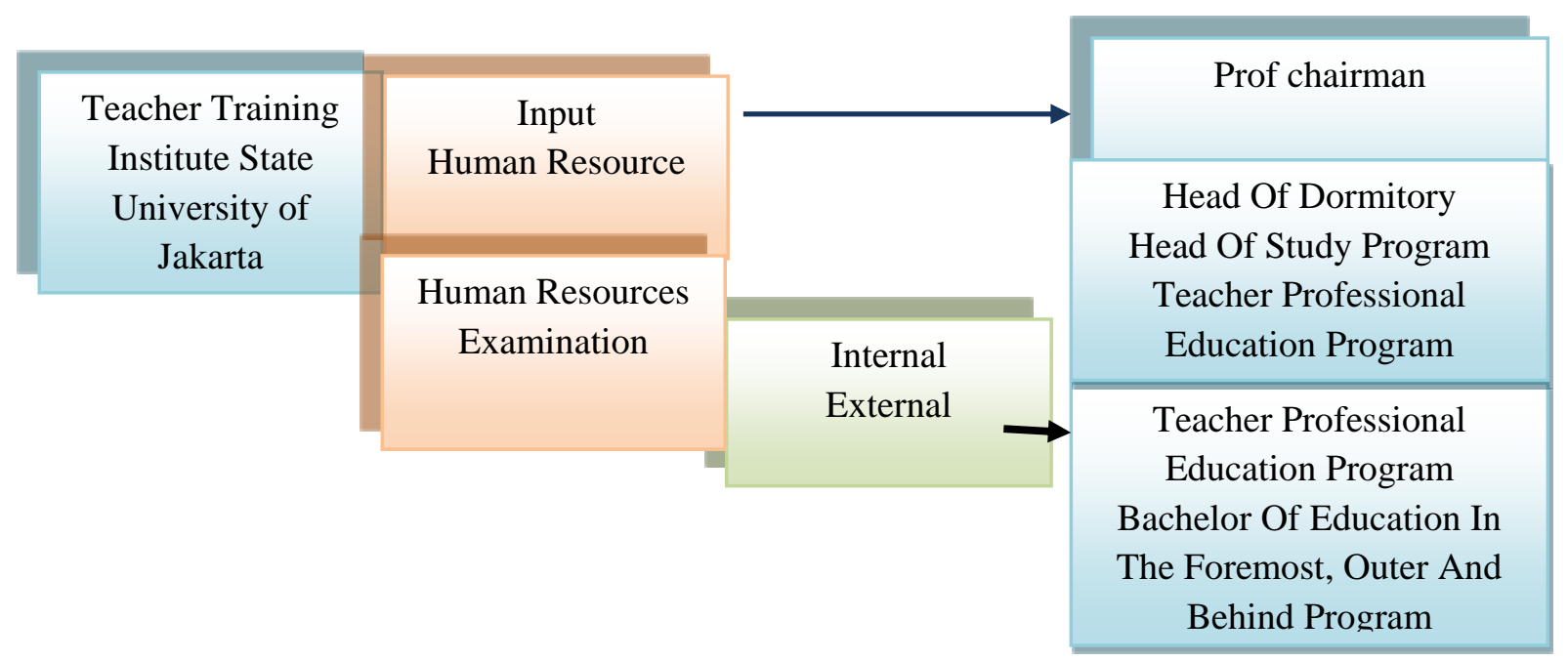

Picture. 7. Factors that Determine Human Resources

Human resources examination summarizes that Teacher Training Institute State University Of Jakarta needs to see the skills and capabilities of all human resources and must be reviewed both internally and externally. In this context evaluation there are two problems found, namely facilities and infrastructure and funds. With regard to facilities and infrastructure, it has not yet fully been able to provide appropriate support facilities. This problem was found during the workshop and micro teaching participants often moved due to the space limit. Lecturers and participants sometimes complain about these limitations, sometimes the participants had to move locations to conduct workshop activities.

Another problem was funding. Funds should be in line with program implementation activities. The late disbursement of funds had become one of the obstacles and causes Teacher Training Institute State University of Jakarta also often late in providing services or paying the salaries of teaching lecturers. This certainly affects the convenience for the lecturers so that there were lecturers who were less eager in carrying out the task, come late, less motivation, and less serious in implementing learning.

\section{Process Evaluation}


Internal process evaluation is; learning implementation activities and products. Implementation of activities cannot be separated from the method of learning, the availability of facilities and infrastructure, media, as well as learning strategies.

The main problem found in the implementation was the coordination of the workshop implementation of learning device development that did not settle in one particular class. Although the classroom had been prepared in Study Center and Teacher Certification hall on 6th floor, sometimes the participants had to move to faculty of Sport Science building located on campus B and closer dormitory.

The implementation of workshop, Field Experience Program, And Dormitory Activities Of Teacher Professional Education Program Bachelor of Education In The Foremost, Outer And Behind participants went smoothly. Discipline issues, some participants did not comply with the provisions when asking permission to leave the dormitory for a need or seeing their family. The main problem in the implementation was the coordination of the workshop implementation of the learning device development that did not settle in one particular class. Although the classroom had been prepared in Study Center and Teacher Certification building on 6th floor, sometimes participants had to move to Faculty of Sport Science building located on campus B and closer to the dormitory. This was because participants needed materials and props of sports equipment available in the faculty. Then, the transfer of class during the workshop. While other obstacles were found on boarding life that had participants from various ethnic groups in Indonesia. In the development of personality and social competence the manager sometimes experienced psychological constraints. Peer groups were sometimes still found in boarding life.

Monitoring and evaluation in general were conducted formally and informally. Formally it was done during State University of Jakarta Leaders Meeting Attended By Chairman Of Program Supervisory Board As State University of Jakarta Teacher Professional Education Program Bachelor of Education In The Foremost, Outer And Behind manager. In the meeting the head of the university could conduct direct evaluation on the implementation of Teacher Professional Education Program Bachelor of Education In The Foremost, Outer And Behind. Informally, the head of the university could notice it from the presence of State University of Jakarta leaders in various activities of Teacher Professional Education Program Bachelor of Education In the Foremost, Outer And Behind participants.

\section{Product Evaluation}

Product evaluation of Teacher Professional Education Program Bachelor of Education In The Foremost, Outer And Behind program implemented by State University of Jakarta from regeneration in the sense of increasing the number of participants did not exist, considering the participants quota of each Teacher Training Institute was the authority of the ministry. But in terms of quality, Teacher Professional Education Program Bachelor of Education In The Foremost, Outer And Behind participants every year continued to show better quality towards academic and boarding life. Teacher Professional Education Program Bachelor of Education In The Foremost, Outer And Behind program also a Field experience program boarding life education. Through the various program activities that had been designed, aspects of the personality, social attitudes and independence of Teacher Professional Education Program Bachelor of Education In The Foremost, Outer And Behind participants were fostered and developed in accordance with the objectives of Teacher Professional Education Program Bachelor of Education In The Foremost, Outer And Behind. Teacher Professional Education Program Bachelor of Education In The Foremost, Outer And Behind participants also experienced an increase in personal, social, and self-reliant attitude of life. 
The complete figure of professional teachers' competence includes; the ability to know in depth the students served, the mastery of the field of study in science and education is the ability of packing educational learning materials, the ability to organize educational learning which includes: learning design, implementation of learning, assessment of process and results, the use of the results of assessment on the process and learning outcomes as a trigger for continuous improvement, and ongoing professional development. The graduation of Teacher Professional Education Program Bachelor of Education In The Foremost, Outer And Behind program of physical, sport and health education was related to three competencies namely; knowledge, skills, and attitude.

The products or results that can be seen from Teacher Professional Education Program Bachelor of Education In The Foremost, Outer And Behind program are: output, covering outcomes achieved by Teacher Professional Education Program Bachelor of Education In The Foremost, Outer And Behind program managers such as $80 \%$ graduates, and outcomes, including long-term impact on professionalism development of a prospective teacher and the improvement of education quality.

SWOT Analysis: Education of Physical, Health and Recreation

\begin{tabular}{|c|c|c|}
\hline \multirow[t]{2}{*}{ Internal } & Strengths & Weakness \\
\hline & 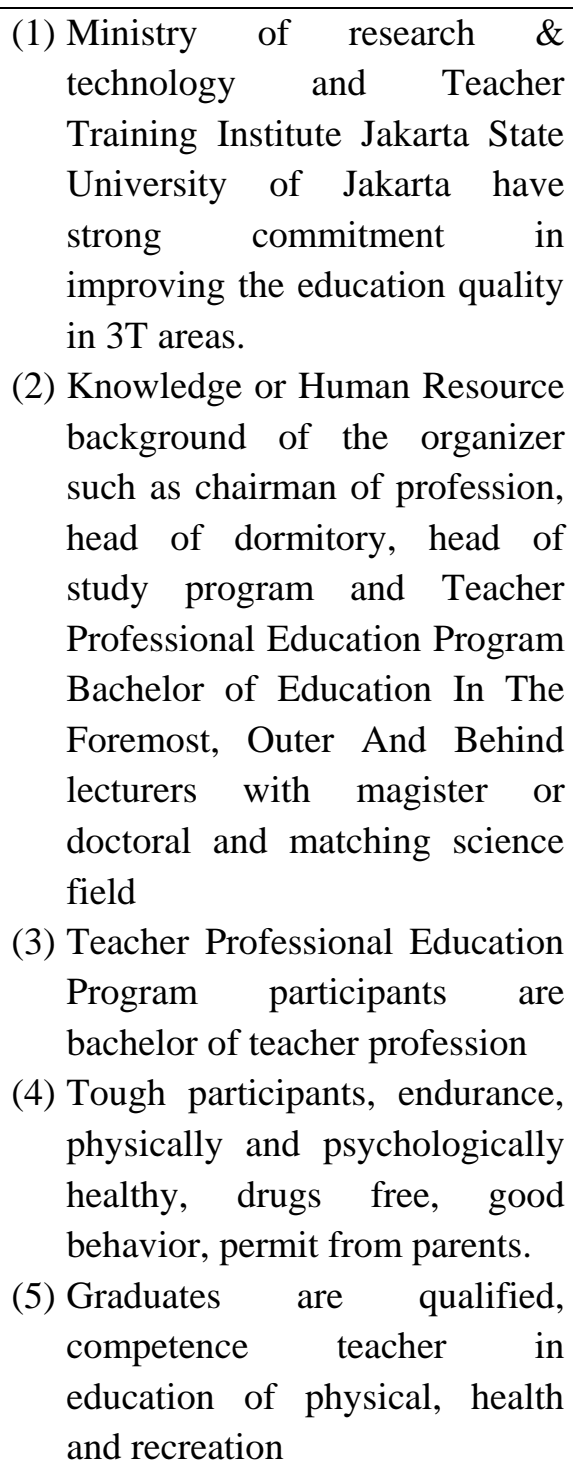 & $\begin{array}{l}\text { (1) Lack of socialization from } \\
\text { organizer institution to public } \\
\text { especially people and students } \\
\text { graduates } \\
\text { (2) Tendency of participants make } \\
\text { peer based on their regional } \\
\text { (3) Facilities and infrastructure are } \\
\text { not adequate such as room for } \\
\text { workshop and peer teaching } \\
\text { (4) The late funds delivery so that } \\
\text { the doer institution doesn't } \\
\text { give fund in the right time to } \\
\text { lecturers or participants } \\
\text { (5) There are graduates who } \\
\text { haven't got job after the } \\
\text { education } \\
\text { (6) Lack of graduates creativity to } \\
\text { create their own work field so } \\
\text { it isn't in line between } \\
\text { graduates and government's } \\
\text { program }\end{array}$ \\
\hline External & & \\
\hline
\end{tabular}




\begin{tabular}{|c|c|c|}
\hline Opportunities & 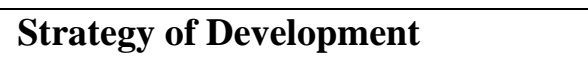 & \\
\hline $\begin{array}{l}\text { (1) Low HR quality in } \\
\text { regions so } \\
\text { professional, qualified } \\
\text { teachers are needed } \\
\text { (2) Facilities and } \\
\text { infrastructure are not } \\
\text { adequate, give } \\
\text { opportunity for } \\
\text { graduates to develop } \\
\text { learning mode, } \\
\text { strategy, method and } \\
\text { media } \\
\text { (3) It is proper to improve } \\
\text { quality and } \\
\text { professionalism of } \\
\text { physical, sport and } \\
\text { health education } \\
\text { teachers } \\
\text { (4) Educational staff can } \\
\text { face the reality of life } \\
\text { in } 21 \text { st century } \\
\text { (5) Teachers can give } \\
\text { problem solving } \\
\text { learning pattern } \\
\text { (6) Low of physical } \\
\text { facilities quality, } \\
\text { teachers' quality, low } \\
\text { students achievement, } \\
\text { low equality } \\
\text { opportunity }\end{array}$ & $\begin{array}{l}\text { 1. Adding the number of } \\
\text { participants } \\
\text { 2. Completing facilities and } \\
\text { infrastructure as needed such as } \\
\text { room for workshop, peer teaching } \\
\text { 3. Improving lecturers quality with } \\
\text { the lowest education qualification } \\
\text { S3 } \\
\text { 4. The improving of research } \\
\text { performance and lecturers' } \\
\text { devotion } \\
\text { 5. Increasing students Teacher } \\
\text { Professional Education Program } \\
\text { Bachelor Of Education In The } \\
\text { Foremost, Outer And Behind } \\
\text { participants involvement in } \\
\text { workshop activities with the } \\
\text { lecturers }\end{array}$ & $\begin{array}{l}\text { 1. Giving opportunity to non } \\
\text { educational bachelor to join the } \\
\text { selection } \\
\text { 2. Cooperate with other institution } \\
\text { especially in improving facilities } \\
\text { and infrastructure } \\
\text { 3. Sending lecturers to continue } \\
\text { study, sending to various } \\
\text { workshops of learning design, } \\
\text { media development as keynote } \\
\text { speakers. } \\
\text { 4. Improving } \\
\text { implementation } \\
\text { 5. Before implementation giving } \\
\text { participants chance observation } \\
\text { to know 3T areas } \\
\text { 6. Direct appointment } \\
\text { participants to teach directly in } \\
\text { the practice areas } \\
\text { 7. Sending participants to continue } \\
\text { study abroad based on their } \\
\text { skills }\end{array}$ \\
\hline Threat & \multicolumn{2}{|l|}{ Strategy of Improvement } \\
\hline $\begin{array}{l}\text { (1) } 21 \text { st century education } \\
\text { demands teachers to } \\
\text { be creative, able to } \\
\text { innovate } \\
\text { (2) Competition of } \\
\text { education quality in } \\
\text { other country } \\
\text { (3) Incoming other } \\
\text { educational institution } \\
\text { which has better } \\
\text { quality teachers' } \\
\text { (4) Low so the } \\
\text { competence so lost the } \\
\text { competition with } \\
\text { teachers in advance }\end{array}$ & $\begin{array}{l}\text { 1. Developing lecturers' and } \\
\text { participants' creativity through } \\
\text { learning process that stress on } \\
\text { innovation } \\
\text { 2. Improving participants' and } \\
\text { lecturers' competence to attend } \\
\text { workshop, comparative study on } \\
\text { educational system in other } \\
\text { country } \\
\text { 3. Completing facilities and } \\
\text { infrastructure in line with need } \\
\text { and the advance of information } \\
\text { technology development } \\
\text { 4. Conducting sharing with other } \\
\text { more advance colleges }\end{array}$ & $\begin{array}{l}\text { 1. Supporting and facilitating the } \\
\text { establishment of creativity } \\
\text { development study center } \\
\text { 2. Cooperate with another schools } \\
\text { 3. Providing labor workshop and } \\
\text { micro teaching that are } \\
\text { appropriate with the need } \\
\text { 4. Completing the supporting } \\
\text { facilities and infrastructure }\end{array}$ \\
\hline
\end{tabular}




\begin{tabular}{|c|c|}
\hline $\begin{array}{l}\text { areas } \\
\text { (5) Inadequate facilities } \\
\text { and infrastructure } \\
\text { (6) Other educational } \\
\text { institutions hold big } \\
\text { market share } \\
\text { (7) The difficult } \\
\text { transportation access, } \\
\text { the difficult areas, and } \\
\text { the low family's } \\
\text { educational } \\
\text { background }\end{array}$ & $\begin{array}{l}\text { 5. Putting the students in superior } \\
\text { schools in Jakarta and region } \\
\text { before putting them in } 3 \mathrm{~T} \text { areas } \\
\text { 6. Performing media based learning }\end{array}$ \\
\hline
\end{tabular}

\section{SWOT Strategy Analysis}

\section{Internal environmental analysis}

Internal environmental analysis (IEA) in the form of observation and identification of the conditions, concerning the organization, operational costs, organizational effectiveness, human resources, facilities and infrastructure and available funds. Observation was done by grouping the things that were the strength or weakness of the organization in order to realize the goals and target.

Participants were educational graduates who seek to develop their own potential through the participants as an input component in Teacher Professional Education Program Bachelor Of Education In The Foremost, Outer And Behind input system which was then processed in the educational process, thus becoming a professional and qualified teacher. The stages of participants management are as follows. a) the participants' needs analysis, b) recruitment, c) selection, d) orientation, e) placement in dormitories, f) education, fostering and development, g) teaching in the foremost, outermost and underdeveloped areas, $\mathrm{h}$ ) writing and reporting.

The objective of Teacher Professional Education Program Bachelor of Education In The Foremost, Outer And Behind program was successfully implemented seen from graduation and alumni almost 100 percent. Student or participant management viewed from stages of education time length in Jakarta State University can be divided into three stages, namely, acceptance, learning process and preparation to enter school or work as professional teacher.

Internal facilities and infrastructure should be managed as best as possible in accordance with the following provisions; (1) complete, ready for use at any time, strong, and durable, (2) tidy, clean, beautiful and soothing, so cooling view and comfortable when used in the learning process, (3) creative, innovative, responsive and varied, (4) Long life use through careful planning to avoid tidal dismantling tendencies, and (5) have special place for worshipping such as mosque.

Curriculum analysis, educational materials and internal teaching and learning process need to be considered by all parties involved, especially for the chairman of the profession, head of dormitory, head of study program, and lecturer especially to improve human resources. The internal funding issue is one of the determinants of the program success. The late in fund disbursement can have a significant impact on the achievement of Teacher Professional Education Program Bachelor Of Education In The Foremost, Outer And Behind program objectives. The government needs to change the flow of funding by accelerating the disbursement of funds. Disbursement of funds can be done before the program activities, this will provide good motivation for institutions, organizers, lecturers, and Teacher Professional Education Program Bachelor of Education In the Foremost, Outer And Behind program participants. 


\section{External environmental analysis}

External environmental analysis (EEA) in the form of observation and identification of environmental conditions outside the organization that may comprise of the environments of economic, technological, social, cultural, political, ecological and security of this observation will generate indication on opportunities.

Social environment of society. The community had very important role on the existence, sustainability and even progress of Teacher Professional Education Program Bachelor of Education In The Foremost, Outer And Behind program. At least one of the determinants of destiny is society. In addition, the relationship with the community aims, among others, as follows: (a) promoting the quality of growth and learning, (b) giving permission to participants, especially as participants parent, (c) establishing cooperation and relationships with schools, especially schools in foremost, outermost and underdeveloped areas, and (d) strengthening the objectives and improving the quality of life and livelihood of the community.

\section{CONCLUSION}

Based on the evaluation result of Teacher Professional Education Program Bachelor Of Education In the Foremost, Outer And Behind program with CIPP model seen from context, input, process, and product in the whole had been done very well. The results of the context evaluation focused on three aspects that were categorized good were the aspect of objectives, legal basis, and needs analysis, they were also in very good category. Input evaluation in Teacher Professional Education Program Bachelor of Education In The Foremost, Outer And Behind Program viewed from Human Resources, Availability of Facilities and Infrastructure, Availability of Funds, and Partnership found problems; facilities and infrastructure were not yet complete, and disbursement of funds. Human Resources in Teacher Professional Education Program Bachelor of Education In The Foremost, Outer And Behind program was in very good category. Process evaluation was the implementation of the evaluation process, decision-making process, learning process, and determining the graduation were categorized very good. Product evaluation was quality improvement, and target of Teacher Professional Education Program Bachelor of Education In The Foremost, Outer And Behind graduates was categorized good.

\section{REFERENCE}

Arikunto,Suharsimi et al.(2004). Evaluation of Educational Programs, Theoretical Guidelines for Educational Practitioners. Jakarta: Bumi Aksara.

Abdul Mohammad Wahid Usmani, et al. (2012)."Meta Evaluation of a Teacher Evaluation Program Using CIPP Model," Archives Des Sciences Vol 66 (7).

Djaali and Pudji Muljono, (2008). Measurement in the Education Sector Jakarta: PT Grasindo.

Daniel L. Stufflebeam, et al.(2006). Evaluating Training Programs of The Four Level Third Edition San Francisco: Berrett Kohler Publishers.

Daniel L Stuffebean and Anthony J.Shinkfield,(1984). Systematic Evaluation Massachusettts: klulwer-Nijhioff Publishing.

Eseryel Deniz, (2002). "Approaches to Evaluation of Traning: Theory and Practice, Educational Technology and Society," Vol. 5 (2).

Musa Sabari,(2005). Evaluation of Learning Program and Community Empowerment. Bandung: Ypin Indonesia.

Tangkudung, James.(2008). Sports Coaching Sports Achievement Coaching. Jakarta: Smart Jaya. .(2016) Miscellaneous Methods Research.Jakarta: lens Media Reader.

Rustad Supriadi,(2015). Guidance of Professional Preparatory Teacher Program BC-3T Program. Jakarta: Directorate General of Higher Education.

Sukardi. (2008). Evaluation of Education Principles and Operations. Jakarta: BumiAksara. 
Journal of Indonesian Physical Education and Sport Vol. 4 (1), July 2018 